ankara Turizm FAKüLtesi DERgisi

Dergi Ana Sayfası: https://dergipark.org.tr/tr/pub/ahbvtfd

ISSN: $2687-1912$

DOI: $10.34189 / \mathrm{tfd} .24 .02 .005$

\title{
Covid 19 Pandemi Sürecinde İnternetten Tatil Satın Alma Kararının Algılanan Değer ve Algılanan Riskten Etkilenme Düzeyi
}

(The Level of Affected By The Perceived Value and Perceived Risk of The Decision to Purchase Holidays on The Internet During The Covid 19 Pandemic Process)

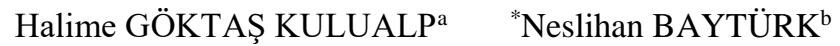 \\ ${ }^{a}$ Karabük Üniversitesi, Safranbolu Turizm Fakültesi, Turizm İşletmeciliği Bölümü, Karabük-Türkiye (halimegoktas@karabuk.edu.tr) \\ https://orcid.org/0000-0002-1485-3026 \\ b Karabük Üniversitesi, Lisansüstü Eğitim Enstitüsü, Turizm İşletmeciliği Anabilim Dalı, Karabük-Türkiye (polatneslii@ @otmail.com) \\ https://orcid.org/0000-0001-6599-1114
}

MAKALE GEÇMIŞ่̇

Gönderim Tarihi:

29.07.2021

Kabul Tarihi:

11.11.2021

\section{Anahtar Kelimeler:}

Algılanan Değer

Algılanan Risk

Satın Alma Niyeti

Tüketici Davranıșı

Covid 19

Keywords:

Perceived Value

Perceived Risk

Purchasing Intention

Consumer Behavior

Covid 19

Makalenin Türü: Araştırma Makalesi

\section{ÖZ}

\begin{abstract}
Tüketiciler günlük hayatlarında yüzlerce uyarıcıya maruz kalmakta ve bu uyarıcıları kendi kişisel tecrübeleri ve istekleri doğrultusunda yorumlayarak satın alma ya da almama kararı vermektedir. Tüketici davranışında satın alma kararında etkili olan önemli unsurlardan biri de algılanan değer ve algılanan risktir. $\mathrm{Bu}$ kapsamda araştırmanın amacı, algılanan değer ve algılanan riskin tüketicilerin internetten tatil satın alma niyetleri üzerindeki etkisini belirlemektir. Araştırmanın örneklemi tesadüfi yolla seçilen 3 Maliye Bakanlığı birimi çalışanlarıdır. Veri toplama yöntemi olarak anket tekniğinden yararlanılmıştır. Bulgulara göre, internetten tatil satın alan tüketiciler tarafindan algılanan değer ve algılanan değerin alt boyutlarının satın alma niyeti üzerinde anlamlı ve olumlu yönde etkisi vardır. Ancak, algılanan risk ile satın alma niyeti arasında istatistiki bir ilişki olmadığı belirlenmiştir.
\end{abstract}

\section{ABSTRACT}

Consumers are exposed to hundreds of stimulants in their daily lives. It interprets these stimulants in line with their personal experiences and wishes and decides whether to buy or not. Perceived value and perceived risk are one of the important factors that affect the purchasing decision of consumer behavior. In this context, the aim of the research is to determine the effect of perceived value and perceived risk on consumers' intentions to purchase holidays online. The sample of the study is the employees of 3 Ministry of Finance units randomly selected. Questionnaire technique is used as data collection method. According to the findings, the perceived value and the sub-dimensions of perceived value by consumers who buy vacations online have a significant and positive effect on purchase intention. However, it is determined that there is no statistical relationship between perceived risk and purchase intention.

*Sorumlu Yazar: Neslihan BAYTÜRK

E posta: polatneslii@hotmail.com

Makalenin Künyesi: Kulualp, H. G. ve Baytürk, N. (2021). Covid 19 Pandemi Sürecinde İnternetten Tatil Satın Alma Kararının Algılanan Değer ve Algılanan Riskten Etkilenme Düzeyi. AHBVÜ Turizm Fakültesi Dergisi, 24 (2), 260-283. 


\section{GIRIŞ}

Değer ve risk algılamaları, ürünün tüketiciler için oluşturduğu maliyetten etkilendiği gibi tüketicinin ürüne ilişkin fayda algısından da oldukça fazla etkilenmektedir. Ürünün tüketiciye olan faydasından kalite algısı, ürünün tüketici için maliyetinden ise onların ürün için harcadığı çaba, enerji, zaman ve para gibi unsurlar kastedilmektedir. Tüketicilerin algıladıkları risk ise, onların ürüne sahip olmak için harcadığı maddi ve maddi olmayan unsurların karşılığında beklentilerinin karşılanmaması olarak tanımlanabilmektedir.

Tüketiciler geleneksel yöntemlerle alışveriş yapmaktansa internetten üzerinden alışveriş yapmayı tercih ederek, araştırma verilerini etkilemektedirler. Türkiye İstatistik Kurumu'nun (TÜİK, 2020) tüketicilerin internetten alışveriş yapma oranlarını belirlemeye yönelik yaptığı araştırma verilerine göre internet üzerinden alışveriş yapanların oranı 2018'de \%29,3 iken 2019 yılında bu oran \%34,1 olarak tespit edilmiştir. TÜİK (2020) verileri aynı zamanda, internetten alışveriş yapanların \%31,7' sinin seyahat ile ilgili alışveriş yaptı̆̆ını da göstermektedir. Geleneksel ve internet kanalı yöntemiyle ürün satın alma, tüketicilere faklı alışveriş deneyimleri kazandırmaktadır. Bilişim teknolojilerinin hızla geliştiği 2000'li yıllarda, tüketiciler farklı alışveriş deneyimleri olan tüketicilerle internet aracılığıyla iletişim kurarak onların deneyimlerini öğrenmekte ve yorumlarını almaktadırlar. Bu yorumlar, satın alma kararını olumlu ya da olumsuz yönde etkileyebilmektedir.

Covid 19 pandemisi ile birlikte web tabanlı dijital platformlar (internet) aracılığı ile alışveriş, geleneksel alışveriş yönteminden daha çok tercih edilmiştir. İnternetten ya da geleneksel alışveriş yöntemleri tüketiciler üzerinde farklı etkilere sahiptir ve tüketiciler bu etkiler altında alışveriş yöntemine karar vermektedir. Örneğin, tüketicilerin değer ve risk algıları internetten ya da geleneksel yöntemle alışveriş yapma kararını etkileyen önemli bir etkidir (Kaya ve Özen, 2012). Tüketiciler satın alma davranışını geleneksel kanalla ya da internet kanalıyla yapma kararını, bu kanallara yönelik değer ve risk algısına göre şekillendirmektedir. Üretici ya da satıcıların tüketicilerin mağazada algıladıkları değerin internette algıladıkları değere göre nasıl bir değişim gösterdiğini belirlemeleri, değerin satın almaya olan etkisinin hangi kanalda daha fazla olduğunu anlamalarının önemli olduğu düşünülmektedir. Aynı zamanda, risk ve değer algılamalarının tüketicilerin satın alma niyetine nasıl etki yaptığının araştırılması, web alışveriş sitesi girişimcileri ve geleneksel mağaza yöneticilerine tüketici davranışlarını değerlendirmek açısından ışık tutacaktır. 


\section{ALGILANAN DEĞER KAVRAMI}

Değer, ürünlerin tüketicilere sağladığı faydayı ifade etmektedir (Kotler, 1999). Müşterilerin hissettikleri değer, onların ihtiyaç ve isteklerine göre farklılık gösterebilmektedir. İşletmeler açısından müşterilerinin beklentileri veya ödünleri ayrı bir öneme sahiptir. Müşterilerin algıladığı faydalar ile ilgili beklentiler, ürünün özelliklerine göre oluşmaktadır. Onların algıladıkları ödünleri ise risk, yaşam eğrisi maliyetleri, işlem maliyetleri oluşturmaktadır (Odabaş1, 2000). Ürünlerin, pazarlamada müşteri kesimlerinin tümüne hitap etmesi çok mümkün olmadığından, yöneticiler, piyasada hangi kesimlere ağırlık vereceğine karar vermelidir. Daha sonra, hedef kesimin, firmanın kendisine sunmakta olduğu ürün ya da hizmetin kapsadığı temel üstünlüğü görebilmeleri için, firmanın piyasaya sunduğu şeyleri müşterilere iyi ifade etmek gerekmektedir (Kotler, 1999). Algılanan değer, tüketiciye sunulan faydaların toplamı; işletme ve rakipleri tarafından sağlanan söz konusu faydaların gerçek performansları ile müşteriler açısından algılanan performansları ve ürün ile ilgili faydaların, müşteriler için göreceli biçimde sahip olduğu önem olmak üzere dört unsurdan oluşmaktadır (Sexton, 2008).

Algılanan değer; algılanan kalite, algılanan fayda, harcama, miktar gibi birçok boyutu da içerisinde barındırmaktadır. Bu farklı boyutlar, belli ürün sınıflarına göre farklı şekillerde oluşmaktadır (Altıntaş, 2000). Müşteri değeri, tüketicilerin satın aldıkları ürün ile ilgili elde ettikleri fayda ile onların ürünlere ilişkin katlanmaları gereken durumlar ile arasındaki bağdır (Selvi, 2007).

Değer, tüketici için bir ürüne sahip olabilmek için katlandıkları ödünler ile (çaba, zaman, para) aynı ürün ile ilgili elde ettikleri faydalar arasındaki farktır. Tüketiciler bu karşılaştırmayı yaparken ürünün kalite ve fiyatının yanı sıra değeri oluşturan birçok unsuru da göz önünde bulundurmaktadır (Zeithaml, 1988; Akt. Bekar, 2012). Sweeney ve Soutar ise (2001) tüketicilerin algıladıkları değeri marka düzeyinde incelemiş ve duygusal değer, fonksiyonel değer, maddi değer, sosyal değer olmak üzere dört boyut belirlemişlerdir. Fonksiyonel değer, üründen algılanan kalite ve beklenen kalite temeline dayanmaktadır. Algılanan maddi değer ise söz konusu ürünün onun için ödenen fiyata uygun olup olmadığına dair tüketicinin ne algıladığını içermektedir.

Duygusal değer, ürün markasının tüketicide oluşturduğu hislerden dolayı ulaşılan sosyal değer ve markaya ait piyasada oluşan sosyal kabullenme durumundan sağlanan faydadır. Sweeney 
ve Soutar (2001) çalışması satın alma davranışının hem fayda hem de haz veren yönlerini içermesinden dolayı ürüne ilişkin algılanan değeri kapsamlı olarak açıklayan bir çalışmadır.

\section{ALGILANAN RISK}

Risk kavramı, belirsiz sonuçları olan tercih durumu ile ilişkilidir. Risk için kazanmayı ve kaybetmeyi barındıran bir olgu olan, piyango/çekiliş en tipik örnek olarak verilebilmektedir. Tüketici satın alma davranışında algılanan risk, olumsuz neticeler üzerine odaklanmaktadır (Stone ve Gronhaug, 1993).

Tüketiciler ürünleri dokunarak, tadına bakarak, koklayarak, yani hissederek satın almak istemektedir. Çünkü, bireyler herhangi bir konudaki algılanan risk düzeyini azaltmak için, pek çok duyuya hitap eden uyarıcılara dayanan nesneleri, algılama çabası içine girmektedir. Geert Hofstede'in yaptığı karşılaştırmalı kültür araştırmasına göre Türkiye'deki risk algılaması ve riskten kaçınma katsayısı oldukça yüksek bir değer olan 85 'tir. Bu veriler de Türkiye'de insanların önemli derecede görerek, dokunarak, tadarak, koklayarak satın alma eğiliminde olmalarını açıklamaktadır (Koç, 2007: 214). Tüketiciler satın alma kararı verirken risk algılamaları durumunda aşağıda sıralanan dört stratejiden birine yönelmektedir (Roselius, 1971):

- Olumsuz sonuç olasılığını veya sonucun olumsuz olması durumunda yaşanacak zararın önemini azaltmak,

- Algılanan riskin boyutları arasında tercihte bulunmak (örneğin, sosyal riski azaltmak için finansal riski göze olmak),

- Alışverişi ertelemek,

- Alışverişi yapmak ve olumsuz sonuca ilişkin yaşanabilecek riski üstlenmek/kabullenmek.

Satın alma davranışında algılanan risk türleri fiziksel risk, sosyal risk, psikolojik risk, finansal risk, performans riski şeklinde sınıflandırılmaktadır (Jacoby ve Kaplan, 1972). Fiziksel risk tüketicinin satın almış olduğu ürün ile ilgili doğrudan güvenlik ya da sağlık ile ilgili bir risk taşıma olasılığıdır. Sosyal risk ise, toplumda tüketicinin çevresinde yer alan insanların satın alma davranışını algılamalarına ilişkin risk türüdür. Yani satın alınan ürünün bireyin çevresi tarafından ona yakıştırılmaması olasılığıdır. Psikolojik risk, satın alma davranışında bulunan bireyin kendisi ile ilgilidir. Aldığı ürün ile kendi imajı arasında uyum olmaması olasılığıdır. Finansal risk, tüketicinin satın aldığı ürün ile ilgili parasal kayıp yaşadığını hissetme 
olasılığıdır. Performans risk, üründen beklenen verimin sağlanamaması olasılığıdır (Jacoby ve Kaplan, 1972).

İnternetten satış yapan firmalar, güven duygusunu hedef kitlelerinde oluşturarak, algılanan riski azaltmak niyetindedirler (Karabulut ve Aksoy, 2009). Tüketici açısından risk değişkeninin, internet kanalı ile yapılan alışverişler üzerindeki etki derecesinin belirlenmesi, bu risklerin giderilmesine ilişkin çözümler geliştirebilmek açısından, internetten satış yapan firmalara yarar sağlayabilecektir (Karabulut ve Aksoy, 2009).

\section{ALGILANAN DEĞER, ALGILANAN RİSK VE SATIN ALMA NIYYTİ ÍLE İLGİİ} AMPÍRIK ÇALIŞMALAR

Literatürde online alışveriş üzerine pek çok çalışma olduğu gibi tüketicinin algıladığı değerin alışveriş üzerindeki etkisini farklı değişkenlerle birlikte ele alan çalışmalar da bulunmaktadır. Örneğin, Varan (2008), 18 yaş üstü İstanbul tüketicilerinin alışverişinde algıladikları değerin müşteri sadakati ve güven üzerinde anlamlı bir etkisi olduğunu saptamıştır. Sanchez ve diğerleri (2008), İspanya'da turistlerin algılanan değerini ölçen ve işlevsel değer, profesyonellik, kalite değeri, maddi değer, sosyal değer ve duygusal değer boyutlarından oluşan bir ölçek geliştirmiştir. Çalışmada, turizm işletmelerinin rekabet avantajı sağlamak için tüketicilerinin algılarını yönetmeleri gerektiği belirtilmiştir. Algılanan risk ve satınalma niyeti üzerine yapılan bir başka çalışmaya göre (Bülbül ve Özoğlu, 2014), Türkiye'de algılanan risk ve satın alma davranışını tüketici yenilikçiliğinin etkilediği saptanmıştır. Algılanan riskin yüksekliği satın alma niyetini engelleyen bir unsurdur. Algılanan değerin önemini aktaran Alarçin (2015), GSM sektöründe yer alan firmalarda operatörlerin ürününde farklılık oluşturarak müşterilerinin algıladığı değerde artış sağlayacağını belirtmiştir.

Online alışveriş üzerine yapılan çalışmalardan biri olan Yılmaz (2010), internet üzerinden alışverişte müşterinin değer algısı, memnuniyeti ve markaya olan güveni arasındaki ilişki incelenmiş ve Eskişehir Anadolu Üniversitesi öğretim elemanlarında algılanan değerin güveni ve memnuniyeti pozitif etkilediği tespit edilmiştir. Online alışveriş üzerine yapılan bir diğer çalışma da (Yenilmez, 2019) Zara Mağazasının online alışveriş yapan müşterilerinde akış deneyimi boyutlarının memnuniyet ve satın alma niyeti üzerinde en yüksek etkiye sahip olan kanalın mobil mağaza kanalı olduğu sonucuna ulaşılmıştır. Karabulut (2013), Muğla-İzmir tüketicileri üzerinde yaptığg çalışmada, tüketicilerin internet üzerinden alışveriş yaparken satın 
alma kararlarında olabildiğince riskten kaçınarak daha garantici davranmayı tercih ettiklerini belirlemiştir.

Yerli literatür incelendiğinde algılanan değer, algılanan risk ve satın alma niyeti konuları ile ilgili çok sayıda çalışma (Özen, 2019; Başarır, 2011; Odabaşı ve Oyman, 2002; Dörtyol, 2014; Karabulut, 2014; Akturan, 2007; Alarçin, 2015) olmasına karşın tüketicilerin değer algısı, risk algısı ve satın alma niyeti konularından iki konuya birlikte odaklanan (Küpeli, 2014; Kanca, 2012) sınırlı sayıda çalışma bulunmaktadır. Bununla birlikte, tüketicilerin algıladığ1 değer ve risk kavramlarının internetten tatil alma davranışında nasıl bir etki gösterdiğini araştıran bir çalışmaya da rastlanmamıştır. Bu açıdan çalışmanın torik olarak katkı sağlaması beklenmektedir.

Yapılan çalışmalar incelendiğinde, tüketicilerin istedikleri anda internet kanalını kullanarak alışveriş yapabilmelerinin tüketicilere cazip geldiği söylenebilir. Tüketici tercihlerini ve satın alma niyetlerini açıklamada, tüketicilerin algıladığı değer kalıplarına hitap eden stratejilerin, perakendecilerin satışlarını artırdığı da düşünülmektedir. Bu anlamda, çalışma uygulama alanına da katkı sunacaktır.

Rekabetin yoğun olduğu turizm sektöründe, turizm işletmelerinin ayakta kalabilmeleri, karlılıklarını artırabilmeleri ile mümkün olabilir (Vodeb, 2012). Ancak, bunu gerçekleştirirken işletme yöneticilerinin tüketicilerin risk ve değer algılarını iyi analiz etmeleri ve bu verileri doğru değerlendirmeleri gerektiği de göz ardı edilmemelidir (Gültaş ve Yıldırım, 2016). Bu doğrultuda, bu çalışmanın amacı, internetten tatil satın alan tüketicilerin, bir ürünü satın alırken, algıladıkları değer ve algıladıkları riskin satın alma niyetine etkisini araştırmaktır. Araştırma verileri Covid 19 Pandemi dönemi içerisinde elde edilmiştir. Böylece, online alışverişin arttığı bir dönemde tüketicilerin algıladığı değer ve risk kavramlarının online tatil alma davranışına nasıl yansıdığı değerlendirilmiştir.

\section{ARAŞTIRMANIN YÖNTEMI}

Araştırmada verilerin toplanması için internet üzerinden anket yöntemi kullanılmıştır. Algılanan değeri ölçmek için, Sweeney ve Soutar (2001) tarafindan geliştirilen Perval ölçeğinden ve algılanan riski ölçmek için ise Stone ve Granhaug (1993) tarafından geliştirilen ölçeklerden yararlanılmıştır. Soru kağıdında kullanılan ifadeler, 1 "Kesinlikle Katılmıyorum, 2 "Katılmiyorum", 3 "Fikrim yok", 4 "Katılıyorum" ve 5 "Kesinlikle Kat1lıyorum" olmak üzere 5'li Likert tipi ölçek ile derecelendirilmiştir. Çalışma sonunda toplanan veriler SPSS 
(Statistical Package for Social Science) paket programı yardımıyla analiz edilmiştir. Değişkenler arası ilişki Basit Doğrusal Regresyon Analizi ile test edilmiştir. Araştırmada algılanan değer ve algılanan riskin internetten tatil satın alan tüketicilerin satın alma kararına etkisi araştırılmış ve literatür araştırması kapsamında bir model oluşturulmuştur.

Daha önce yapılan çalışmalarda bir ürün ya da hizmet ile ilgili algılanan değer ve alt boyutları (Zeithamll, 1988; Sweneey ve Souter,1999; Sanchez ve Fernandez, 2009) incelenmiştir. Ayrıca, algılanan risk kavramı ve pazarlama literatüründeki önemi de (Roselius,1971; Jacoby ve Kaplan,1972) incelenmiş ve bu bağlamda birçok araştırmaya kaynak olmuştur. Algılanan değer, algılanan risk ve satın alma niyeti üzerine yapılan çalışmalarda (Özen, 2011; Başarır, 2019; Bülbül, 2014; Yeşilyurt, 2018; Yeniçeri, 2018; Sarıyer, 2008; Şahin, 2018; Turan, 2009; Uygun, 2011; Varan, 2008; Yağc1, 2017; Sünnetçioğlu ve Yıldırım, 2019) tüketicilerin, değer ve risk algılarının satın alma niyetine etkisi ile ilgi kurulmuştur. Söz konusu çalışmalardan yola çıkılarak araştırmada öngörülen model ve yapılan literatür taraması kapsamında hipotezler aşağıdaki gibi belirlenmiştir:

H1: İnternetten tatil satın alan tüketiciler için Algılanan Değer Satın alma Niyetini anlamlı ve olumlu yönde etkilemektedir.

H1a: İnternetten tatil satın alan tüketiciler için Algılanan Fonksiyonel ve Duygusal Değer Satın alma Niyetini anlamlı ve olumlu yönde etkilemektedir.

H1b: İnternetten tatil satın alan tüketiciler tarafından Algılanan Maddi Değer Satın alma Niyetini anlamlı ve olumlu yönde etkilemektedir.

H1c: İnternetten tatil satın alan tüketiciler tarafından Algılanan Sosyal Değer Satın alma Niyetini anlamlı ve olumlu yönde etkilemektedir.

H1d: İnternetten tatil satın alan tüketiciler tarafından Algılanan Kalite Değeri Satın alma Niyetini anlamlı ve olumlu yönde etkilemektedir.

H2: İnternetten tatil satın alan tüketiciler tarafından Algılanan Risk Satın alma Niyetini anlamlı ve olumsuz yönde etkilemektedir.

H2a: İnternetten tatil satın alan tüketiciler tarafından Algılanan Zaman ve Maddi Kayıp Riski Satın alma Niyetini anlamlı ve olumsuz yönde etkilemektedir.

H2b: İnternetten tatil satın alan tüketiciler tarafından Algılanan Psikolojik Risk Satın alma Niyetini anlamlı ve olumsuz yönde etkilemektedir. 
H2c: İnternetten tatil satın alan tüketiciler tarafından Algılanan Güven Riski Satın alma Niyetini anlamlı ve olumsuz yönde etkilemektedir.

H2d: İnternetten tatil satın alan tüketiciler tarafından Algılanan Sosyal Risk Satın alma Niyetini anlamlı ve olumsuz yönde etkilemektedir.

H3: İnternetten tatil satın alan tüketiciler tarafından Algılanan Risk Algılanan Değeri anlamlı ve olumsuz yönde etkilemektedir.

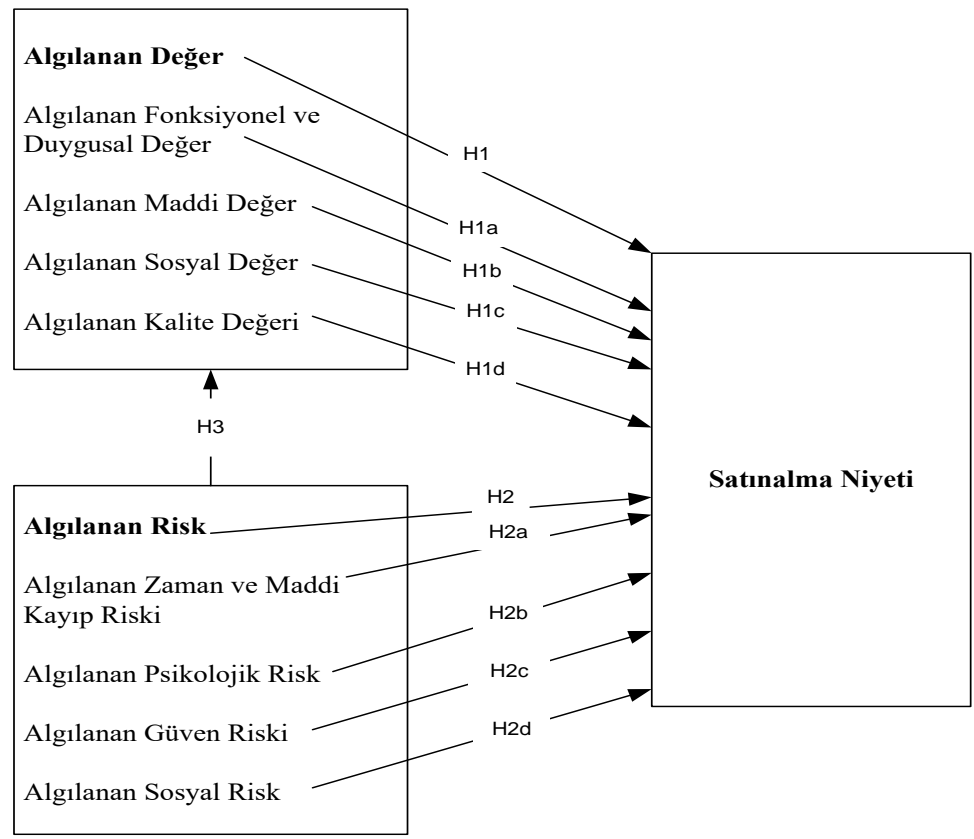

Şekil 1. Araştırmanın modeli

Covid 19 Pandemisi sürecinde yapılan araştırma için araştırmacı tarafından araştırmanın ulaşılabilirlik ve kontrol edilebilirlik açısından daha sağlıklı yürütülmesi amacıyla örnekleme yöntemine başvurulmuştur. Bu amaçla, anket uygulaması tek bir kurumda gerçekleştirilmiştir. Anket formları Maliye Bakanlığı personeline e-posta gönderme aracılığıyla uygulanmıştır. Anketlerin uygulanması için Karabük Üniversitesi Sosyal ve Beşeri Bilimler Araştırmaları Etik Kurulu 30.06.2020 tarihli ve 2020/08 sayılı Etik Kurulu İzni alınmıştır. Maliye Bakanlığı'na bağlı 21 adet bakanlık birimi arasından tesadüfi yolla seçilen üç birimde (Kamu Mali Yönetim ve Dönüşüm Genel Müdürlüğü, Gelir İdaresi Daire Başkanlığı, Muhasebat Genel Müdürlügü) görev yapan 950 çalışana araştırmanın amacı, konusu ve anketi içeren epostalar atılmıştır. Belirli sürelerle hatırlatma e-postaları da gönderilmiştir. Anket uygulaması üç aylık süreçte tamamlanmıştır. Araştırma kapsamında 272 kişiden veri toplanmış ancak eksik ya da hatalı doldurma sebebiyle 7 kişinin anketi analiz dışında tutulmuştur. Böylece 265 
kişiden elde edilen veriler analiz edilmiştir. Covid 19 Pandemi dönemindeki gerek çalışma yöntemlerindeki değişikliğe uyum süreci ve gerekse araştırmanın sadece bir kurumda yürütülmesi gibi sebepler araştırmanın kısıtlı tarafını oluşturmaktadır.

\section{BULGULAR}

\subsection{Faktör Analizi Bulguları}

Araştırmanın değişkenleri olan algılanan değer, algılanan risk ve satın alma niyeti ölçeklerinin güvenilirlik analizi sonuçlarına göre, Cronbach Alpha katsayılarının sırayla 0,943, 0,936 ve 0,902 olduğu saptanmıştır. Değerler 0,800 ila 1,000 arasında olduğu için ölçek yüksek derecede güvenilirdir (Kalayc1, 2017:405). Araştırma verilerinin normal dağılıma uygunluğu Çarpıklık (Skewness) ve Basıklık (Kurtosis) değerlerine göre tespit edilmiştir. Değerler, $\pm 1,96$ değerleri arasında ve 0,05 anlamlılık düzeyinde olduğu için (Tabachnick ve Fidell, 2001) normal dağılıma uygundur. Faktör analizi sonuçlarına göre, ortak varyans (communality) değerleri ve ölçek maddelerinin değerleri 0,40' tan düşük olmamalıdır (Field, 2000: 434).

Tablo 1. Algılanan değer ölçeği açıklayıcı faktör analizi bulguları

\begin{tabular}{|c|c|c|c|c|}
\hline & $\begin{array}{l}\text { Alg,Fonksiyonel ve } \\
\text { Duygusal Değer }\end{array}$ & Alg.Maddi Değer & Alg.Sosyal Değer & $\begin{array}{c}\text { Algılanan Kalite } \\
\text { Değeri }\end{array}$ \\
\hline Değer_11 & 0,765 & & & \\
\hline Değer_13 & 0,723 & & & \\
\hline Değer_5 & 0,714 & & & \\
\hline Değer_12 & 0,710 & & & \\
\hline Değer_14 & 0,698 & & & \\
\hline Değer_16 & 0,693 & & & \\
\hline Değer_10 & 0,685 & & & \\
\hline Değer_4 & 0,681 & & & \\
\hline Değer_1 & 0,678 & & & \\
\hline Değer_3 & 0,669 & & & \\
\hline Değer_6 & 0,617 & & & \\
\hline Değer_17 & 0,561 & & & \\
\hline Değer_7 & 0,533 & & & \\
\hline Değer_9 & 0,482 & & & \\
\hline Değer_19 & & & 0,858 & \\
\hline Değer_21 & & & 0,829 & \\
\hline Değer_20 & & & 0,810 & \\
\hline Değer_18 & & & 0,807 & \\
\hline Değer_2 & & & 0,595 & \\
\hline Değer_23 & & & 0,576 & \\
\hline Değer_25 & & & 0,463 & \\
\hline Değer_27 & & 0,707 & & \\
\hline
\end{tabular}




\begin{tabular}{|c|c|c|c|c|}
\hline Değer_29 & & 0,664 & & \\
\hline Değer_24 & & 0,638 & & \\
\hline Değer_36 & & 0,634 & & \\
\hline Değer_37 & & 0,630 & & \\
\hline Değer_26 & & 0,621 & & \\
\hline Değer_28 & & 0,614 & & \\
\hline Değer_38 & & 0,556 & & \\
\hline Değer_32 & & 0,533 & & \\
\hline Değer_30 & & 0,517 & & \\
\hline Değer_22 & & 0,463 & & \\
\hline Değer_33 & & 0,416 & & \\
\hline Değer_39 & & & & 0,754 \\
\hline Değer_35 & & & & 0,553 \\
\hline Değer_34 & & & & 0,492 \\
\hline Değer_31 & & & & 0,431 \\
\hline Değer_15 & & & & 0,427 \\
\hline Özdeğer & 12,367 & 4,543 & 1,934 & 1,786 \\
\hline $\begin{array}{l}\text { Açıklanan } \\
\text { Varyans Oranı }\end{array}$ & 32,544 & 11,954 & 5,09 & 4,699 \\
\hline Ortalama & 4,183 & 4,004 & 2,746 & 3,022 \\
\hline
\end{tabular}

Açıklanan Toplam Varyans: 68,415 KMO: 0,914 Bartlett Testi p<0,000

Algılanan değer ölçeği ile gerçekleştirilen açıklayıcı faktör analizi sonuçlarına göre, algılanan değer sorularından 8. Soru olan "Bir tatil sitesini uzun süre incelemek o sitenin kullanımıyla ilgili alışkanlık yapar” değişkeninin faktör yükü düşük olduğu için analizden çıkarılmış ve faktör analizi tekrarlanmıştır. $\mathrm{Bu}$ analiz sonucunda, algılanan değer ölçeği 4 boyuttan oluşmaktadır (Tablo 1). Boyutlar, algılanan fonksiyonel ve duygusal değer, algılanan maddi değer, algılanan sosyal değer ve algılanan kalite değeri şeklinde isimlendirilmiştir. İsimlendirme işlemi, literatüre bağlı kalınarak söz konusu ölçeği kullanan çalışmalar incelenerek yapılmıştır.

Tablo 2. Algılanan risk ölçeği açıklayıcı faktör analizi bulguları

\begin{tabular}{|c|c|c|c|c|}
\hline & $\begin{array}{c}\text { Zaman ve } \\
\text { Maddi } \\
\text { Kayıp } \\
\text { Riski } \\
\end{array}$ & $\begin{array}{l}\text { Psikolojik } \\
\text { Risk }\end{array}$ & $\begin{array}{l}\text { Güven } \\
\text { Riski }\end{array}$ & $\begin{array}{c}\text { Sosyal } \\
\text { Risk }\end{array}$ \\
\hline Risk_1 & & & & 0,728 \\
\hline Risk_2 & & & & 0,703 \\
\hline Risk_3 & & & & 0,668 \\
\hline Risk_4 & & & & 0,546 \\
\hline Risk_5 & & & & 0,468 \\
\hline Risk_8 & 0,793 & & & \\
\hline Risk_7 & 0,750 & & & \\
\hline
\end{tabular}




\begin{tabular}{lllll} 
Risk_6 & 0,702 & & & \\
Risk_9 & 0,592 & & & \\
Risk_10 & 0,571 & & & \\
Risk_14 & 0,531 & & & \\
Risk_15 & 0,476 & & & \\
Risk_21 & & 0,801 & & \\
Risk_20 & & 0,775 & & \\
Risk_19 & & 0,708 & & \\
Risk_11 & & 0,548 & & \\
Risk_17 & & & 0,878 & \\
Risk_16 & & & 0,848 & \\
Risk_18 & & & 0,803 & \\
Risk_12 & & & 0,548 & \\
Risk_13 & 9,918 & 2,12 & 0,493 & \\
Özdeğer & \multirow{2}{*}{1,141} & 1,105 \\
\hline Aç1klanan & & & \\
Varyans Oran1 & 47,228 & 10,095 & 5,433 & 5,263 \\
\hline Ortalama & 2,486 & 2,542 & 3,297 & 2,561 \\
\hline
\end{tabular}

Açıklanan Toplam Varyans: 68,019; KMO: 0,920; Bartlett Testi p $<0,000$

Algılanan risk ölçeği de açıklayıcı faktör analizine tabi tutulmuş ve 4 boyutlu bir yapı elde edilmiştir (Tablo 2). Boyutlar, zaman ve maddi kayıp riski, psikolojik risk, güven riski ve sosyal risk şeklinde isimlendirilmiştir. İsimlendirme işlemi, literatüre bağlı kalınarak söz konusu ölçeği kullanan çalışmalar incelenerek yapılmıştır.

Tablo 3. Satın alma niyeti ölçeği açıklayıcı faktör analizi bulguları

\begin{tabular}{lc} 
& Satın Alma Niyeti \\
\hline Niyet_3 & 0,894 \\
Niyet_4 & 0,874 \\
Niyet_2 & 0,857 \\
Niyet_5 & 0,850 \\
Niyet_1 & 0,747 \\
Özdeğer & 3,576 \\
Açıklanan Varyans Oranı & 71,519 \\
Ortalama & 3,583 \\
\hline
\end{tabular}

Açıklanan Toplam Varyans: 71,519; KMO: 0,854; Bartlett Testi p<0,000

Tablo 3'te satın alma niyeti ölçeğine ait faktör analizi bulguları yer almaktadır. Satın alma niyeti ölçeği orijinalinde olduğu gibi tek boyuttan oluşmaktadır.

Araştırma değişkenleri arasında istatistiki olarak ilişki olup olmadığını belirlemek amacıyla Pearson Korelasyon analizi uygulanmıştır. 
Tablo 4. Değişkenlerin ana boyutlarına ait korelasyon analizi sonuçları

\begin{tabular}{rlllllll}
\hline & & Ortalama & Standart Sapma & $\mathbf{1}$ & $\mathbf{2}$ & $\mathbf{3}$ \\
\hline $\mathbf{1}$ & Algılanan Risk & 2,721 & 0,698 & 1 & & & \\
$\mathbf{2}$ & Algılanan Değer & 3,488 & 0,540 & $0,379^{* *}$ & 1 & & \\
$\mathbf{3}$ & Satınalma Niyeti & 3,583 & 0,745 & 0,088 & $0,555^{* *}$ & 1 & \\
${ }^{p}<0,01$ & & & & & & &
\end{tabular}

Korelasyon analizi bulgularına göre, algılanan değer ve algılanan risk arasında \%37,9'luk $\mathrm{p}<0,01$ düzeyinde anlamlı bir ilişki bulunmaktadır. Satın alma niyeti ile algılanan değer arasında \%55,5'lik p<0,01 düzeyinde anlamlı bir ilişki olduğu tespit edilmiştir. Satın alma niyeti ile algılanan risk arasında anlamlı bir ilişki bulunmamaktadır. Korelasyon analizi bulguları doğrultusunda aralarında beklenen yönde ve anlamlı ilişkiler çıkan algılanan değer ile algılanan risk ve algılanan değer ile satın alma niyeti arasındaki etki analizlerine devam edilmiş ancak, algılanan risk ve satın alma niyeti arasında anlamlı bir ilişki tespit edilmediği için etki analizine bakılmamıştır. Dolayısıyla, "H2: İnternetten tatil satın alan tüketiciler tarafından Algılanan Risk Satın alma Niyetini anlamlı ve olumsuz yönde etkilemektedir" hipotezi kabul edilmemiştir. Değişkenlerin alt boyutlarına ait uygulanan korelasyon analizi sonuçlarına göre, H2a: İnternetten tatil satın alan tüketiciler tarafından Algılanan Zaman ve Maddi Kayıp Riski Satın alma Niyetini anlamlı ve olumsuz yönde etkilemektedir. "H2b: İnternetten tatil satın alan tüketiciler tarafından Algılanan Psikolojik Risk Satın alma Niyetini anlamlı ve olumsuz yönde etkilemektedir". "H2c: İnternetten tatil satın alan tüketiciler tarafından Algılanan Güven Riski Satın alma Niyetini anlamlı ve olumsuz yönde etkilemektedir". "H2d: İnternetten tatil satın alan tüketiciler tarafindan Algılanan Sosyal Risk Satın alma Niyetini anlamlı ve olumsuz yönde etkilemektedir” hipotezleri test edilmemiştir.

\subsection{Araştırma Hipotezlerinin Test Edilmesine İlişkin Sonuçlar}

Araştırma kapsamında, "H1: İnternetten tatil satın alan tüketiciler tarafından Algılanan Değer Satın Alma Niyetini anlamlı ve olumlu yönde etkilemektedir" hipotezinin test edilmesi için uygulanan Basit Doğrusal Regresyon Analizi sonuçlarına göre Algılanan Değer Satın Alma Niyetini pozitif yönde $(\beta=0,765)$ ve anlamlı $(\mathrm{p}<0,01)$ bir şekilde etkilemektedir. Bu durum, internetten tatil satın alan tüketicilerin algıladıkları değerdeki 1 birimlik artışın satın alma niyetlerini 0,765 birim artıracağını göstermektedir. Bu bilgiler doğrultusunda, H1 hipotezi kabul edilmiştir. Bu bağlamda tüketicilerin turistik ürünü satın alırken algıladıkları değer, 
ürün ya da hizmet ile ilgili yaşamayı bekledikleri olumlu tecrübelerin gerçekleşeceğine inanmalarına neden olabilmekte ve satın alma niyetini olumlu yönde etkilemektedir.

Tablo 5: Regresyon analizi sonuçları

\begin{tabular}{llccc}
\hline & \multicolumn{4}{c}{ Bağımlı Değişken: Satın Alma Niyeti } \\
\hline Bağımsız değişkenler & \multicolumn{1}{c}{$\boldsymbol{\beta}$} & $\mathbf{t}$ & $\begin{array}{c}\text { Anlamlılık } \\
(\mathbf{p})\end{array}$ & $\begin{array}{c}\text { Sonuç } \\
\text { KABUL }\end{array}$ \\
Algılanan Değer & 0,765 & 3.664 & $0,000^{* *}$ & $\begin{array}{l}\text { KABU } \\
\text { (H1) }\end{array}$ \\
Model Sabit Değer & 0,915 & & & \\
Model F & 117,054 & & & \\
$\mathrm{R}^{2}$ & 0,305 & & & \\
$* * \mathrm{p}<0,01$ & & & &
\end{tabular}

Tablo 6. Algılanan değerin alt boyutlarının satın alma niyeti üzerindeki etkisine yönelik regresyon analizi sonuçları

\begin{tabular}{|c|c|c|c|c|}
\hline \multicolumn{5}{|c|}{ Bağımlı Değişken: Satın Alma Niyeti } \\
\hline Bağımsız değişkenler & $\boldsymbol{\beta}$ & $\mathbf{t}$ & $\begin{array}{c}\text { Anlamlılık } \\
\text { (p) }\end{array}$ & Sonuç \\
\hline $\begin{array}{l}\text { Algılanan Fonksiyonel Ve } \\
\text { Duygusal Değer }\end{array}$ & 0,187 & 2,273 & $0,024 *$ & KABUL (H1a) \\
\hline Algılanan Maddi Değer & 0,209 & 2,237 & $0,026^{*}$ & KABUL (H1b) \\
\hline Algılanan Sosyal Değer & 0,119 & 2,373 & $0,018 *$ & KABUL (H1c) \\
\hline Algılanan Kalite Değeri & 0,273 & 4,268 & $0,000 * *$ & KABUL (H1d) \\
\hline Model Sabit Değer & 0,822 & & & \\
\hline $\begin{array}{l}\text { Model F } \\
\mathrm{R}^{2}\end{array}$ & $\begin{array}{l}30,096 \\
0,306\end{array}$ & & & \\
\hline
\end{tabular}

Araştırma kapsamında, "H1a: İnternetten tatil satın alan tüketiciler tarafından Algılanan Fonksiyonel ve Duygusal Değer Satın Alma Niyetini anlamlı ve olumlu yönde etkilemektedir", "H1b: İnternetten tatil satın alan tüketiciler tarafından Algılanan Maddi Değer Satın Alma Niyetini anlamlı ve olumlu yönde etkilemektedir", "H1c: İnternetten tatil satın alan tüketiciler tarafından Algılanan Sosyal Değer Satın Alma Niyetini anlamlı ve olumlu yönde etkilemektedir", "H1d: İnternetten tatil satın alan tüketiciler tarafindan Algılanan Kalite Değeri Satın Alma Niyetini anlamlı ve olumlu yönde etkilemektedir" hipotezlerinin test edilmesi için uygulanan Çoklu Regresyon Analizi sonuçlarına göre Algılanan Fonksiyonel ve Duygusal Değer Satın Alma Niyetini pozitif yönde $(\beta=0,187)$ ve 
anlamlı ( $p<0,05)$, Algılanan Maddi Değer Satın Alma Niyetini pozitif yönde $(\beta=0,209)$ ve anlamlı ( $p<0,05)$, Algılanan Sosyal Değer Satın Alma Niyetini pozitif yönde $(\beta=0,119)$ ve anlamlı $(\mathrm{p}<0,05)$ ve Algılanan Kalite Değeri Satın Alma Niyetini pozitif yönde $(\beta=0,273)$ ve anlamlı $(\mathrm{p}<0,01)$ bir şekilde etkilemektedir. $\mathrm{Bu}$ durum, internetten tatil satın alan tüketicilerin algıladıkları fonksiyonel ve duygusal değerdeki 1 birimlik artışın satın alma niyetlerini 0,187 birim artıracağını; algıladıkları maddi değerdeki 1 birimlik artışın satın alma niyetlerini 0,209 birim artıracağını; algıladıkları sosyal değerdeki 1 birimlik artışın satın alma niyetlerini 0,119 birim artıracağını ve algıladıkları kalite değerindeki 1 birimlik artışın satın alma niyetlerini 0,273 birim artıracağını göstermektedir. Dolayısıyla, H1a, H1b, H1c ve H1d hipotezleri kabul edilmiştir. Tüketicilerin algıladıkları fonksiyonel, duygusal, maddi, sosyal değer ve kalite değeri ile satın alma niyetleri arasında olumlu ve pozitif yönde bir ilişki olduğu bulunmuştur. Bu bağlamda tüketiciler, turistik ürün satın alırken ürün ya da hizmet ile ilgili elde edecekleri faydanın yaşayacakları kayıplardan daha fazla olduklarını düşündüklerinde satın alma niyetlerinde olumlu yönde bir eğilim görülmektedir.

Tablo 7. Algılanan riskin algılanan değer üzerindeki etkisine yönelik regresyon analizi sonuçları

\begin{tabular}{|c|c|c|c|c|}
\hline & \multicolumn{4}{|c|}{ Bağımlı Değişken: Algılanan Değer } \\
\hline Bağımsız değişkenler & $\boldsymbol{\beta}$ & $\mathbf{t}$ & $\begin{array}{c}\text { Anlamlılık } \\
\text { (p) }\end{array}$ & Sonuç \\
\hline Algilanan Risk & 0,294 & 21,668 & 0 & $\begin{array}{l}\text { RED } \\
\text { (H3) }\end{array}$ \\
\hline Model Sabit Değer & 2,689 & & & \\
\hline Model F & 44,158 & & & \\
\hline $\mathrm{R}^{2}$ & 0,141 & & & \\
\hline
\end{tabular}

Algılanan riskin algılanan değer üzerindeki etkisine yönelik regresyon analizi bulguları kapsamında, "H3: İnternetten tatil satın alan tüketiciler tarafından Algılanan Risk Algılanan Değeri anlamlı ve olumsuz yönde etkilemektedir” hipotezinin test edilmesi için basit doğrusal regresyon analizi yapılmıştır. Sonuçlara göre; algılanan risk algılanan değeri pozitif yönde $(\beta=0,294)$ ve anlamlı $(\mathrm{p}<0,01)$ bir şekilde etkilemektedir. Bu nedenle, H3 hipotezi kabul edilmemiştir. $\mathrm{Bu}$ bağlamda, internetten tatil satın alan tüketiciler, satın almayı düşündükleri turistik ürünün, kendilerine para ve zaman açısından ek bir maliyet yarattığını düşünerek risk algılasalar dahi, bu alışverişin kendisine sosyal değer katıp, onun toplum tarafından kabul 
görmesini sağlayacağını düşündüğü için, algılanan riskin, algılanan değeri anlamlı ve olumlu yönde etkilediği düşünülmektedir. Benzer şekilde, Küpeli (2014)'ün çalışmasında da kurulan hipotezin tersine algılanan risk algılanan değeri olumlu yönde etkilemektedir.

\section{SONUÇ VE ÖNERILER}

2000'li yıllarda teknolojinin oldukça gelişmesi nedeni ile insanlar günlük hayatlarındaki birçok eyleminde interneti kullanabilmektedir. İnternet kanalı ile alışveriş yapmak da bu aktivitelerden sadece bir tanesidir. Hizmet sektörünün önemli bir kolu olan turizm alanında da internet kanalı ile tatil satın alma oranının \%34,1 e yükseldiği tespit edilmiştir (TUİK, 2020). $\mathrm{Bu}$ nedenle turizm sektöründe internet kanalı ile hizmet satan turizm şirketlerine yol göstermesi ve sektörde ilerleyen girişimcilere destek olması girişimcilere destek olması amacı ile bu çalışma yapılmıştır. Bu çalışmada tüketici davranışı ile başlanılan yolda, tüketicinin karar verme sürecine etki eden değer algısı ve risk algısı ve bu kavramların alt boyutları da tüm detayları ile incelenmiştir. Tüketiciler satın alma kararı verirken birçok etki altında kalabilmektedir. $\mathrm{Bu}$ etkiler, onların kişilikleri, öğrenmiş oldukları bilgiler, aileleri ya da demografik özelliklerinden, ait oldukları kültür ve sosyal sınıftan kaynaklanmaktadır. Tüketiciler, bazı zamanlarda daha düşük fiyat, ürüne hızlı ve kolay erişim, promosyon, taksit olanakları gibi durumlarda internet üzerinden alışverişe yönelebilmekte ve satın alma niyetini etkileyebilmektedir. Tüketici satın alma davranışını inceleyen birçok çalışmada müşterinin kararına etki edebilecek alt boyutların etkisinin incelendiği söylenebilir.

Covid 19 pandemi sürecinde çevrimiçi alışverişin tüketici davranışlarında süreklilik göstermesi açısından, onların değerlerini ve yaşam stillerini araştırmak oldukça önemlidir. Bu durum firmalara, tüketici eğilimlerine ilişkin sağlıklı bilgiler sağlayacaktır. Böylece dijital ortamda yaşanan rekabette de üstünlükler olacaktır. İnternet kanalı ile hizmet alma, bu alanda hizmet veren perakendecilerin web sayfalarındaki çeşitliliği artırmaları, sosyal medya tanıtımlarına ağırlık vermeleri, tüketicilerin yaşam tarzlarına hitap eden özel ürün teklifleri, Covid-19 salgın sürecinin uzaması, ya da toplumu etkileyen farklı durumların ortaya çıkması durumunda hatta pandemi sonrasında bile, zaman alan faaliyetleri azaltmış olmak adına tüketiciler tarafından tercih edilebilecektir (Çakıroğlu vd., 2020).

İnternetten tatil satın alan tüketicinin, ürüne yönelik duygusal, fonksiyonel ve sosyal değer algısı ile satın alma niyeti arasındaki ilişkinin olumlu ve güçlü yönde olduğu söylenebilir. 
Aynı tüketicinin algıladığı riskler satın alma niyetini beklendiği gibi olumsuz yönde etkilemediği, ürüne yönelik algılanan risklerin yukarıda bahsedilen nedenlerden dolayı değer algısını da olumsuz yönde etkileyemediği söylenebilir.

Satışlarında internet kanalını kullanan ya da kullanmayı düşünen işletmelerin, alacakları stratejik kararlarında, tüketicilerin satın alma süreçlerini aydınlatan bu araştırmanın bulgularını göz önünde bulundurmalarının faydalı olacağına inanılmaktadır. $\mathrm{Bu}$ araştırma kapsamında, algılanan değer ve alt boyutlarıyla tüketicinin satın alma niyeti arasında anlamlı ve pozitif yönlü ilişki olduğu tespit edilmiştir. Dolayısıyla, internetten satış yapan işletme sahipleri ya da girişimcilerin satışlarını artırabilmeleri için tüketicinin algıladığı değer kavramı alt boyutlarına özen göstermeleri ve bu unsurları geliştirmeleri gerekmektedir. Tüketicinin algıladığı risk kavramı ile satın alma niyeti arasında istatistiki bir ilişki bulunmamıştır. Bu nedenle, ileri de yapılacak çalışmalarda tüketicilerin internetten satın alma davranışında algıladığı risk ile satın alma niyeti arasında aracılık etkisi bulunan değişkenlere ilişkin araştırma yapılması önerilmektedir. Ayrıca, tüketicilerin internetten tatil satın alma davranışlarında algıladıkları değer alt boyutları olan algılanan fonksiyonel ve duygusal değer, algılanan maddi değer, algılanan sosyal değer ve algılanan kalite değerini olumlu yönde etkileyen unsurlar üzerinde durulması satın alma davranışlarının artırılmasında etkili olacaktır.

\section{KAYNAKÇA}

Akturan, U. (2007). Satın alma karar sürecinde markaya yönelik algılanan riskin algılanan değer üzerindeki etkisi, Yayınlanmamış Doktora Tezi. İstanbul Üniversitesi, SBE.

Alarçin, M. (2015). Algılanan değerin tüketici karar verme türlerine etkisi ve GSM operatörü kullanıcıları üzerine bir araştırma. Marmara Üniversitesi Üretim Yönetimi ve Pazarlama ABD., Yayınlanmamış Yüksek Lisans Tezi.

Altıntaş, M. H. (2000). Tüketici davranışları-müşteri tatmininden müşteri değerine, Bursa: Alfa Yayınevi.

Başarır, Ö. (2019). Marka farkındalığı ile satın alma niyeti arasındaki ilişki bağlamında televizyon dizilerinde ürün yerleştirme. Yayınlanmamış Doktora Tezi. Marmara Üniversitesi, SBE, İstanbul.

Bekar, T. (2012). Algılanan değerin algılanan marka üzerindeki etkisi. Yayınlanmamış Yüksek Lisans Tezi. Sakarya Üniversitesi Sosyal Bilimler Enstitüsü, Sakarya. 


\section{Ankara Hacı Bayram Veli Üniversitesi Turizm Fakültesi Dergisi \\ Kulualp ve Baytürk, 2021, Cilt: 24, Sayı: 2, 260-283}

Bülbül, H. \& Özoğlu, B. (2014). Tüketici yenilikçiliği ve algılanan riskin satın alma davranışına etkisi. Erciyes Üniversitesi İ̈BF Dergisi, 44, 43-58.

Çakıroğlu, K.L, Pirtini, S. \& Çengel, Ö. (2020). Covid 19 sürecinde post-pandemi döneminde yaşam tarzı açısından tüketici davranışlarının değişen eğilimi üzerine kavramsal bir çalışma, İstanbul Ticaret Üniversitesi Sosyal Bilimler Dergisi, 19 (37),81-103.

Dörtyol, İ. T. (2014). Hizmet kalitesi. İstanbul: Beta Basım A.Ş.

Field, A. (2000). Discovering statistics using SPSS for windows. London, Thousand Oaks, Sage Publications, New Delhi.

Gültaş, P. \& Yıldırım, Y. (2016). “İnternetten alışverişte tüketici davranışını etkileyen demografik faktörler”. Dicle Üniversitesi İ̈BF Dergisi, 6(10), 32-51.

Jacoby J. \& Kaplan, L.B. (1972). The companents of perceived risk, Proceedings of the Third Annual Conference of the Association for Consumer Research, 382-393.

Kalaycı, Ş. (2017). SPSS uygulamalı çok değişkenli istatistik teknikleri, 5. Baskı. Ankara: Dinamik Akademi.

Kanca, B. (2012). Mersin Üniversitesi Merkez Kafeterya'daki yiyecek içecek hizmetlerinin üniversite çalışanları ve öğrencileri tarafından algılanan kalite, algılanan değer ve memnuniyet ve algılanan risk açısından değerlendirilmesi. Mersin Üniversitesi, Yayınlanmamış Yüksek Lisans Tezi.

Karabulut, A. N. (2013). Tüketicilerin algılanan risk değişkeni karşısında internetten alışveriş yapma eğilimlerinin ölçülmesi, beklenen fayda teorisine karşı beklenti teorisi. Journal of Yaşar University (5517).

Kaya, İ. \& Özen, H. (2012). Geleneksel mağazalar ile internetten alışverişte değer algısı ve satınalma niyeti: Bir karşıllaştırma. İstanbul Üniversitesi İşletme Fakültesi Dergisi, 41(1).

Koç, E. (2007). Tüketici davranışları ve pazarlama stratejileri: global ve yerel yaklaşım, Ankara: Seçkin Yayınevi.

Kotler, P. (1999). Kotler on marketing. İstanbul: Sistem Yayıncılık.

Küpeli, T. Ş. (2014). Algılanan risk ve algılanan değer arasındaki ilişkilerin otel müşterileri üzerinde incelenmesi. Hacettepe Üniversitesi, Sosyal Bilimler Enstitüsü, Yayınlanmamış Yüksek Lisans Tezi, Ankara.

Odabaş1, Y. \& Oyman, M. (2002). Pazarlama iletişimi yönetimi. Eskişehir: Kapital Medya Hizmetleri

Odabaş1, Y. (2000). Müşteri ilişkileri yönetimi, İstanbul: Sistem Yayıncılık.

Oğuz, G. V. \& Bilgin, İ. (2017). Kurumsal sosyal sorumluluğun satın alma niyeti üzerindeki etkisi: istanbul ilinde bir araştırma, İGÜ Sosyal Bilimler Dergisi, 4 (2), 51-72. 


\section{Ankara Hacı Bayram Veli Üniversitesi Turizm Fakültesi Dergisi \\ Kulualp ve Baytürk, 2021, Cilt: 24, Sayı: 2, 260-283}

Özen, H. (2011). Geleneksel alı̧̧veriş ile internet üzerinde yapılan alışverişte algılanan değerin satın alma niyetine olan etkisinin karşılaştırılması. İstanbul Üniversitesi, SBE, Yayınlanmamış Doktora Tezi, İstanbul.

Roselius, T. (1971). Consumer rankings of rerceived risk, Journal of Marketing, 35 (1), 56-61.

Sanchez, J., Callarisa, L., Rodriguez, R. M., \& Moliner, M. A. (2006). Perceived value of the purchase of a tourism product. Tourism Management, 27(3), 394-409.

Sánchez-Fernández, R., Iniesta-Bonillo, M. Á. \& Holbrook, M. B. (2009). The conceptualisation and measurement of consumer value in services. International Journal of Market Research.

Sarıyer, N. (2008). Gloval ölçeği ile belediye hizmetlerinde müşterinin algıladığı değerinin belirlenmesi - kayseri büyükşehir örneği, Gazi Üniversitesi İktisadi ve İdari Bilimler Fakültesi Dergisi 10, 163-185.

Selvi, M. S. (2007). İlişkisel pazarlama stratejiler ve teknikler. 1. Baskı. Ankara: Detay Yayıncılık.

Sexton, D. (2008). Pazarlama 101: pazarlamanın en güçlü fikirleri daha fazla müşteri edinmek ve onları tutmak için nasıl kullanılır?, Çeviri: N. Kıvılcım Yavuz, İstanbul: Media Cat Yayınları.

Stone, R. N \& Granhaug. K. (1993). Perceived risk: further considerations for the marketing discipline. Europen Journal of Marketing, 27(3), 39-50.

Sünnetçioğlu, S. \& Yıldırım, H. M. (2019). Sokak yiyeceklerinin tüketiminde satıcıya olan güven, algılanan risk, algılanan fayda, tutum ve satın alma niyeti arasındaki ilişkilerin incelenmesi, Manas Sosyal Araştırmalar Dergisi, 8(3), 2800-2820.

Sweeney, J. C, Souter, G. N \& Johnson L. V. (1999). The role of perceived risk in the quality value relationship: a study in a retail environment. Jornal of Retailing, 75 (1), 77-105.

Sweneey, J. C. \& Souter, N.G. (2001). Consumer perceived value: the development of a multiple item scale. Journal of Retailing, 77(2), 203-220.

Şahin, R. (2018). Fitness merkezlerinde algılanan hizmet kalitesi, algılanan değer, müşteri memnuniyeti ve davranışsal niyetler arasındaki ilişkiler. Yayınlanmamış Yüksek Lisans Tezi, Ege Üniversitesi Sağlık Bilimleri Enstitüsü, İzmir.

Tabachnick, B. G. \& Fidell, L. S. (2001). Using multivariate statistics, 4. Bask1. Needham Heights: Mass. Ally and Bacon.

TUIK (2020). Hanehalk1 İstatistikleri https://data.tuik.gov.tr/Bulten/Index?p=Hanehalki-BilisimTeknolojileri-(BT)-Kullanim-Arastirmasi-2019-

30574\#: :text=T\%C3\%9C\%C4\%B0K\%20Kurumsal\&text=\%C4\%B0nternet\%20kullan\%C4 \%B1m\%C4\%B1\%202019\%20y\%C4\%B11\%C4\%B1nda\%2016,kad\%C4\%B1nlarda\%20\%68 \%2C9\%20oldu. Erişim Tarihi: 20/12/2020. 


\section{Ankara Hacı Bayram Veli Üniversitesi Turizm Fakültesi Dergisi \\ Kulualp ve Baytürk, 2021, Cilt: 24, Sayı: 2, 260-283}

Turan, A. H \& Çolakoğlu, B. (2009). Yaşlı tüketicilerde algılanan marka değeri ve satın alma niyeti. Afyon Kocatepe Üniversitesi İ̈BF Dergisi (C.XI,SI, ). 11(1), 277-296.

Uygun, M., Özçiftçi, V. \& Divanoğlu, S. U, (2011). Tüketicilerin online alışveriş davranışını etkileyen faktörler. Organizasyon ve Yönetim Bilimleri Dergisi, 3 (2), 373-393.

Varan, İ. İ., (2008). İlişkisel alışverişin müşterinin değer algısı üzerindeki etkileri açısından algılanan değer, memnuniyet ve sadakat ilişkisine yönelik bir uygulama. Yayınlanmamış Doktora Tezi Marmara Üniversitesi SBE, İstanbul.

Vodeb, K. (2012). Competition in tourism in terms of changing environment. Procedia-Social and Behavioral Sciences, 44, 273-278.

Yağcı, M. İ \& Mohamed, H. (2017). Tüketicilerin online alışverişe karşı tutumlarını ve online alışveriş yapma niyetlerini etkileyen faktörler: türkiye-slovenya karşılaştırması. Siyaset Ekonomi ve Yönetim Araştırmaları Dergisi. 5 (5), 111-124.

Yeniçeri, T \& Yaraş, E ve Akın, E. (2012). Tüketicilerin riskten kaçınma düzeylerine göre sanal alışveriş risk algısı ve sanal plansız tüketim eğilimlerinin belirlenmesi. Uluslararası İktisadi ve İdari İncelemeler Dergisi, 9 (9), 145-163.

Yenilmez, G. (2019). Algılanan deneyimsel değer ve akış deneyiminin mağaza memnuniyeti ve satın alma niyeti üzerindeki etkileri: Çevrimiçi, fiziksel ve mobil mağaza kanallarının karşılaştırılması. Yayınlanmamış Yüksek Lisans Tezi, Osmaniye Korkut Ata Üniversitesi SBE, Osmaniye.

Yeşilyurt, Ö. (2018). Sağlık işletmesinde algılanan hizmet kalitesi, algılanan risk ve algılanan değer boyutlarının hasta memnuniyeti ve davranışsal niyeti üzerine etkisinin yapısal eşitlik modeli ile değerlendirilmesi. Yayınlanmamış Doktora Tezi. Selçuk Üniversitesi Sosyal Bilimler Enstitüsü. Konya.

Yılmaz, C. (2010). Online alışverişte algılanan değer, memnuniyet, güven ve sadakat arasındaki ilişki. Yayınlanmamış Yüksek Lisans Tezi. Cumhuriyet Üniversitesi, Sivas.

Zeithaml, Valarie A. (1988). Consumer perceptions of price, qualityand value: ameans-end model andsynthesis of evidence. Journal of Marketing, 52, 2-22.

Zeithaml V. A., Bitner, M. J. \& Gremler, D. D (2009). Services marketing: integrating customer focus across the firm, The Mc Grow-Hill Companies, Newyork.

1. Çıkar Çatışması Beyanı: Makale yazarları arasında herhangi bir çıkar çatışması bulunmamaktadır.

2. Etik Kurul İzin Belgesi: Anketlerin uygulanması için Karabük Üniversitesi Sosyal ve Beşeri Bilimler Araştırmaları Etik Kurulu 30.06.2020 tarihli ve 2020/08 sayılı Etik Kurulu İzni alınmıştır.

3. Araştırmacıların Katkı Oranı Beyanı: Makale Neslihan Baytürk tarafından Karabük Üniversitesi Lisansüstü Eğitim Enstitüsü'nde 2021 y1lında tamamlanan yüksek lisans tezinden derlenmiştir. Yazarlar makaleye eşit oranda katkı sağlamıştır. 


\section{The Level of Affected By The Perceived Value and Perceived Risk of The Decision to Purchase Holidays on The Internet During The Covid 19 Pandemic Process Halime GÖKTAȘ KULUALP}

Karabük University, Safranbolu Faculty of Tourism, Karabük/Turkey Neslihan BAYTÜRK

Karabük University, The Institute of Graduate Studies, Karabük/Turkey

\section{Extensive Summary}

Consumers are exposed to hundreds of stimulants in their daily lives. It interprets these stimulants in line with their personal experiences and wishes and decides whether to buy or not. Perceived value and perceived risk are one of the important factors that affect the purchasing decision of consumer behavior. In this context, the aim of the research is to determine the effect of perceived value and perceived risk on consumers' intentions to purchase holidays online. The sample of the study is the employees of 3 Ministry of Finance units randomly selected. Questionnaire technique is used as data collection method. According to the findings, the perceived value and the sub-dimensions of perceived value by consumers who buy vacations online have a significant and positive effect on purchase intention. However, it is determined that there is no statistical relationship between perceived risk and purchase intention.

In the research, online survey method was used to collect data. The Perval scale developed by Sweeney and Soutar (2001) was used to measure the perceived value, and the scales developed by Stone and Granhaug (1993) were used to measure the perceived risk. The statements used in the questionnaire were graded on a 5-point Likert-type scale, with 1 "Strongly Disagree", 2 "Disagree", 3 "I have no idea", 4 "Agree" and 5 "Strongly Agree". The data collected at the end of the study were analyzed with the help of SPSS (Statistical Package for Social Science) package program. The relationship between variables was tested with Simple Linear Regression Analysis. In the research, the effect of perceived value and 
perceived risk on the purchasing decision of consumers who buy vacation from the internet was investigated and a model was created within the scope of literature research.

In previous studies, the perceived value and sub-dimensions of a product or service (Zeithamll, 1988; Sweneey \& Souter,1999; Sanchez \& Fernandez, 2009) were examined. In addition, the concept of perceived risk and its importance in the marketing literature (Roselius, 1971; Jacoby and Kaplan, 1972) have been examined and have been the source of many researches in this context. In studies on perceived value, perceived risk and purchase intention (Özen, 2011; Çağrır, 2019; Bülbül, 2014; Yeşilyurt, 2018; Yeniceri, 2018; Sarıyer, 2008; Şahin, 2018; Turan, 2009; Uygun, 2011; Varan , 2008; Yağc1, 2017; Sünnetçioğlu \& Y1ldrim, 2019) have been interested in the effect of consumers' value and risk perceptions on purchase intention. Based on the aforementioned studies, the model envisaged in the research and the hypotheses within the scope of the literature review were determined as follows:

H1: Perceived Value has a significant and positive effect on the Purchasing Intent for consumers who buy vacations online.

H1a: Perceived Functional and Emotional Value for consumers who buy vacations on the Internet significantly and positively affects the Purchasing Intention.

H1b: The Perceived Material Value of consumers who buy vacations on the Internet significantly and positively affects the Purchasing Intent.

H1c: Social Value Perceived by consumers who buy vacations on the Internet significantly and positively affects the Purchasing Intent.

H1d: Perceived Quality Value by consumers who buy vacations on the Internet significantly and positively affects the Purchasing Intent.

H2: Perceived Risk by consumers who buy vacations on the Internet significantly and negatively affects the Purchasing Intent.

H2a: Perceived Time and Risk of Financial Loss by consumers who buy vacations on the Internet significantly and negatively affect the Purchasing Intention. 
Kulualp ve Baytürk, 2021, Cilt: 24, Sayı: 2, 260-283

H2b: Psychological Risk Perceived by consumers who buy vacations on the Internet significantly and negatively affects the Purchasing Intention.

H2c: Confidence Risk Perceived by consumers who buy vacations on the Internet significantly and negatively affects the Purchasing Intent.

H2d: Social Risk Perceived by consumers who buy vacations on the Internet significantly and negatively affects the Purchasing Intent.

H3: Perceived Risk has a significant and negative effect on Perceived Value by consumers who buy vacations online.

According to the results of the reliability analysis of the perceived value, perceived risk and purchase intention scales, which are the variables of the study, it was determined that the Cronbach Alpha coefficients were 0.943, 0.936 and 0.902, respectively. According to the exploratory factor analysis findings, the perceived value scale has a 4-dimensional structure. The dimensions are perceived functional and emotional value, perceived material value, perceived social value, and perceived quality value. The perceived risk scale is also 4dimensional. The dimensions are the risk of time and financial loss, psychological risk, trust risk, and social risk. The purchase intention scale is one-dimensional. The naming of the dimensions was made according to the literature.

According to the correlation analysis findings, it has been determined that there is a significant relationship between perceived value and perceived risk, and between purchase intention and perceived value. There is no significant relationship between purchase intention and perceived risk. But, there is no significant relationship between purchase intention and perceived risk. The analysis of the variables with significant relationships between them continued. However, the analysis of the variables that did not have significant relationships between them was terminated. Therefore, the sub-hypotheses of $\mathrm{H} 2$ and $\mathrm{H} 2$ were rejected.

According to the results of the regression analysis performed to test H1, Perceived Value positively $(\beta=0.765)$ and significantly $(\mathrm{p}<0.01)$ affect the Purchasing Intent. As a result of testing the sub-hypotheses of H1, Perceived Functional and Emotional Value Purchasing Intent positively $(\beta=0.187)$ and significant $(\mathrm{p}<0.05)$, Perceived Material Value Purchasing 
Intent positively $(\beta=0.209)$ and significant $(p) .<0.05)$, Perceived Social Value Purchasing Intent positively $(\beta=0.119)$ and significant $(p<0.05)$, Perceived Quality Value Purchasing Intent positively $(\beta=0.273)$ and significant $(p<0.01))$ somehow affect it. Simple linear regression analysis was performed to test H3. According to the results; perceived risk affects the perceived value positively $(\beta=0.294)$ and significantly $(\mathrm{p}<0.01)$. Therefore, hypothesis H3 was not accepted.

It is very important to research their values and lifestyles in terms of the continuity of online shopping in consumer behavior during the Covid 19 pandemic process. This will provide companies with healthy information on consumer trends. Thus, there will be advantages in the competition in the digital environment. Receiving services via the internet, retailers providing services in this field increasing the variety on their web pages, giving weight to social media promotions, special product offers that appeal to the lifestyles of consumers, prolonging the Covid-19 epidemic process, or in case of different situations affecting the society, even after the pandemic Even so, it may be preferred by consumers in order to reduce time-consuming activities (Çakıroğlu et al., 2020).

It can be said that the relationship between the emotional, functional and social value perception of the product and the purchase intention of the consumer who buys a holiday online is positive and strong. It can be said that the risks perceived by the same consumer do not affect the purchase intention negatively as expected, and the perceived risks towards the product cannot negatively affect the perception of value due to the reasons mentioned above.

It is believed that it will be beneficial for businesses that use or intend to use the internet channel in their sales, to consider the findings of this research, which illuminates the purchasing processes of consumers, in their strategic decisions. Within the scope of this research, it has been determined that there is a significant and positive relationship between the perceived value and its sub-dimensions and the purchase intention of the consumer. Therefore, business owners or entrepreneurs who sell on the Internet should pay attention to the sub-dimensions of the concept of value perceived by the consumer and develop these elements in order to increase their sales. There was no statistical relationship between the concept of risk perceived by the consumer and the purchase intention. For this reason, it is recommended to conduct research on the variables that have a mediating effect between the 
risk perceived by consumers in their online purchasing behavior and their purchase intention in future studies. In addition, focusing on the factors that positively affect the perceived functional and emotional value, perceived material value, perceived social value and perceived quality value, which are the value sub-dimensions that consumers perceive in their holiday purchasing behavior on the Internet, will be effective in increasing their purchasing behavior. 